\title{
Ground Subsidence Following Groundwater Drawdown by Excavating of 500 m Deep Investigation Shafts in Granite Body in Mizunami, Central Japan in 2004-2012
}

\author{
Fumiaki Kimata, Yasuhiro Asai, Ryo Honda, Toshiyuki Tanaka, Hiroshi Ishii, \\ Rikio Miyajima
}

Tono Research Institute of Earthquake Science, Association for the Development of Earthquake Prediction, Gifu, Japan

Email: kimata@mail.tries.jp, asai@mail.tries.jp, honda@mail.tries.jp, tanaka@mail.tries.jp, ishii@mail.tries.jp, miyajima@mail.tries.jp

Received 12 May 2015; accepted 13 July 2015; published 16 July 2015

Copyright (C) 2015 by authors and Scientific Research Publishing Inc.

This work is licensed under the Creative Commons Attribution International License (CC BY). http://creativecommons.org/licenses/by/4.0/

(c) (i) Open Access

\section{Abstract}

Two $500 \mathrm{~m}$ deep investigation shafts were excavating in the granite body in Mizunami, central Japan by JAEA (Japan Nuclear Cycle Development Institute) in 2004-2012. Groundwater with volume of $700 \mathrm{~m}^{3}$ was generally pumping a day to prevent the shafts from submerging in $\mathbf{2 0 1 2}$ following the excavating. As a result of pumping the groundwater, the ground water level lowered to $60 \mathrm{~m}$ in the borehole with the distance of $200 \mathrm{~m}$ from the excavating shafts in 2012 . Leveling network extending $2 \mathrm{~km} \times 2 \mathrm{~km}$ around the shafts was established to detect the vertical deformation around the shafts in 2004, and precise leveling was done every year. An $18 \mathrm{~mm}$ ground subsidence was detected in the benchmark close to the shafts for 8 years in 2004-2012, and time series of subsidence at benchmark was consistent with the groundwater drawdown. The groundwater drawdown and ground subsidence were caused by the pumping ground water in excavating shafts.

\section{Keywords}

Ground Subsidences, Groundwater Drawdown, 500 m Deep Excavation Shaft, Precise Leveling, Groundwater Drainage 


\section{Introduction}

Ground subsidence caused by pumping up mass ground water in alluvial plains is one of the serious social problems of the present days in not only advanced countries but also developing countries (e.g., [1] [2]). Surely, ground subsidences caused by pumping up are almost partially limited by the regulation of the groundwater pumping in Japan already [3]. Ground subsidences are caused still in the local area by pumping up of the groundwater and gases [4] [5]. Moreover, there is subsidence in not only alluvial plains but also basic rock area [6].

Mizunami, Gifu prefecture is located in the central Japan, and Toki Cretaceous-Paleocene granite complex is distributed as basic rock around there. Toki granite complex is composed of crackles and homogenous rock [7]. The Miocene Mizunami Group (20 - 15 Ma) and the Pliocene Seto Group (5 - $0.7 \mathrm{Ma}$ ) uncomfortably cover the granite. Thin alluvium is distributed along small rivers, such as Toki-gawa and Hiyoshi-gawa. Therefore, there was no report of the ground subsidence in Mizunami historically.

Japan Atomic Energy Agency (JAEA) conducted Mizunami Underground Laboratory (MIU) Project in Mizunami, which is a comprehensive research project investigating the deep underground environment within crystalline rock. The project role is defined in “Framework for Nuclear Energy Policy” by Japan Atomic Energy Commission [8]. The project is ongoing under the agreement of no installation of radioactive-waste and no waste-disposal site in future associated with the lease contract for the Mizunami City-owned land [9]-[11]. Under the project, MIU started the excavating of two deep shafts in Jun 2003, and the shaft depths arrived to $500 \mathrm{~m}$ deep in 2013.

Tono Research Institute of Earthquake Science (TRIES) provides the research on seismic activities, ground deformation, and grand water flow, following the MIU project including development of the observation system.

\section{Excavation Project of $500 \mathrm{~m}$ Deep Shafts in Granite Body in Mizunami}

MUI organizes the excavating project of the $1000 \mathrm{~m}$ deep shafts in Akiyo, western part of Mizunami in 2002 (Figure 1). The main shaft is excavating with a $6.5 \mathrm{~m}$ diameter, and the ventilation shaft is $40 \mathrm{~m}$ south from the main shaft with $4.5 \mathrm{~m}$ diameter. Two shafts are interfaced with transverse galleries every $100 \mathrm{~m}$ deep. In March 2011, the excavating was arrived at $500 \mathrm{~m}$ deep, and the research is undergoing at the depth.

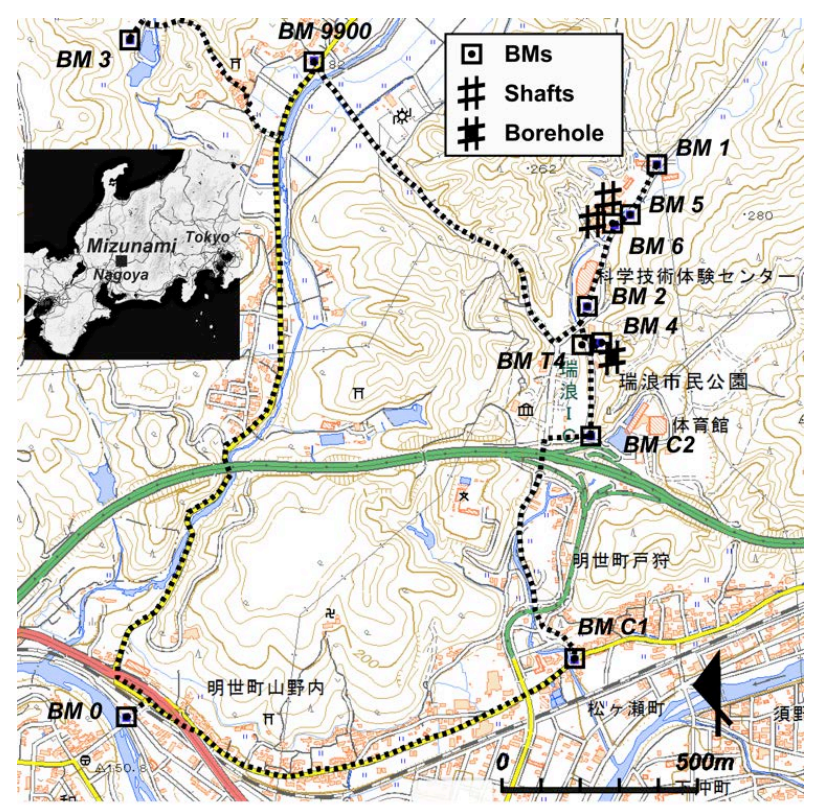

Figure 1. Location map of the $500 \mathrm{~m}$ deep shafts of MIU, JAEA, leveling benchmarks, and ground water level observation borehole. BM 0 constructed in the granite, is the reference point to discuss the vertical deformation. The locations of shafts, bench marks constructed in 2004 and 2006, and groundwater level observation borehole are indicated as \#, $\square, \#$, respectively. 
The Miocene Mizunami Group, including lignite-bearing formation in the lowermost part covers inconsistent with the Toki granite complex in excavating the area [12]. Before the excavating, it is suggested the boundary depth of the Toki granite complex and Mizunami Group [8] and regional ground water flow system based on the $100 \mathrm{~m}$ deep boring logging, airborne electromagnetic survey, gravity survey, and elastic wave exploration. As results of the excavating, plane of the unconformity is about $200 \mathrm{~m}$ deep.

Tono Research Institute of Earthquake Science (TRIES) installed strain meters and tilt meters to monitor the ground deformation and water level pressures to detect the water level changes around the excavating shafts. As it is suggested the ground subsidence, a precise leveling network is also established in the area.

In we discuss the groundwater changes in the observation borehole, and ground deformation detected by the leveling, the locations of the observation borehole and leveling benchmarks are shown in Figure 1.

Leveling benchmarks were constructed in 2004 and are added after then. In 2012, the leveling network is extending over $30 \mathrm{~km}$ long toward northeast and included 60 benchmarks. In this paper, we discussed the vertical deformations detected at the benchmarks constructed until 2007, because of the survey periods. The benchmarks discussed here are distributed in the area of $2 \times 2 \mathrm{~km}$.

\section{Vertical Deformation Detected by the Precise Leveling in 2004-2012}

Precise leveling is conducted, firstly, in February 2004, and it is repeated every year for eight years until March 2011, and two times a year for two years in 2011 and 2012. However, the shaft excavating was begun in July 2003; it was shallow than $20 \mathrm{~m}$ depth in February 2004.

Precise leveling are done by digital level of NA3003 and DNA03 (Leica) and super-invar rods, and round and closure errors are within $2.5 \mathrm{~L}(\mathrm{~km})^{1 / 2}$ and $1.5 \mathrm{~L}(\mathrm{~km})^{1 / 2} \mathrm{~mm}$ respectively. The accuracy complies the first precise leveling of Geospatial Information Authority of Japan (GSI).

Vertical deformations observed for 8.5 years in March 2004-September 2012 are shown in Figure 2. The deformations are shown for four periods of 1) February 2004-March 2007, 2) March 2007-March 2011, 3) March 2011-February 2012, and 4) February 2012-September 2012 in the figure. Some benchmarks are added in March 2006, March 2007 and September 2012.

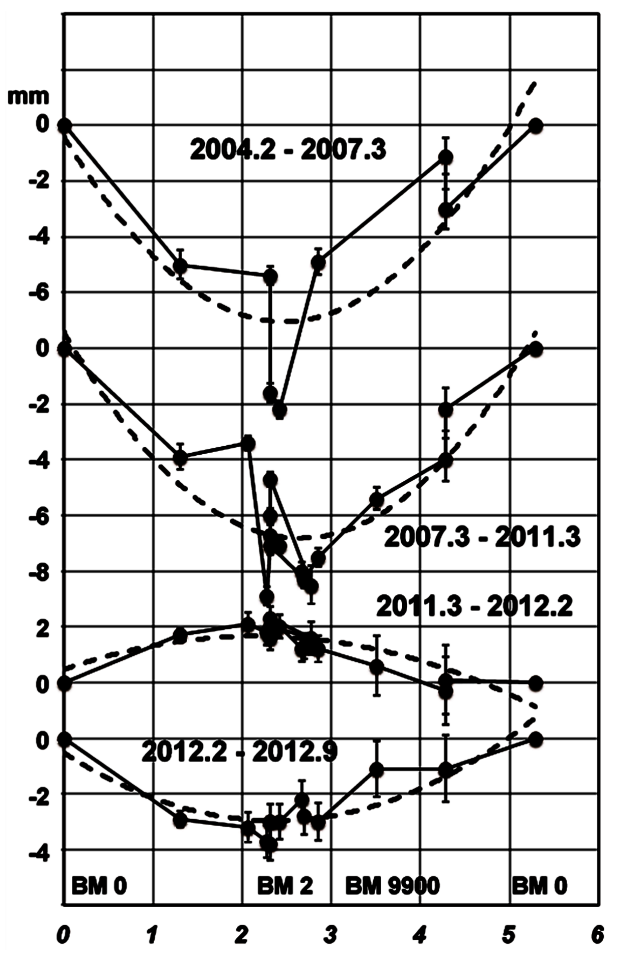

Figure 2. Vertical deformations detected the leveling route around the $500 \mathrm{~m}$ deep shafts of MIU, JAES in four periods of Feb. 2004-Mar. 2007-Mar. 2011-Feb. 2012-Sept. 2012. The height at BM 0 is fixed for the period, and distances are calculated counterclockwise from the BM 0. 
Maximum subsidence of $14 \mathrm{~mm}$ are detected at the BMs 5 and 6, close to the shafts trough the periods of 1), 2) and 4) until March 2011, just before 2011 Tohoku Super Giant earthquake. After the 2011 Tohoku earthquake, subsidence is turned to uplifting of $2 \mathrm{~mm}$ maximally until the leveling in February 2012. In September 2012, deformation is turned to subsidence once more, and it reaches $3 \mathrm{~mm}$ for only seven months in the period of 4 ).

\subsection{Discussion on Deformation Caused by Load off/on by Development Project}

Before the discussion on ground deformation around the shafts, we estimate the effect of load on/off by development project nearby the leveling network. A sallow valley was buried, and a low hill was removed during the survey period (Figure 3(A)). Loading on and off are caused by development, and it is effected the ground deformation of subsidence and uplift.

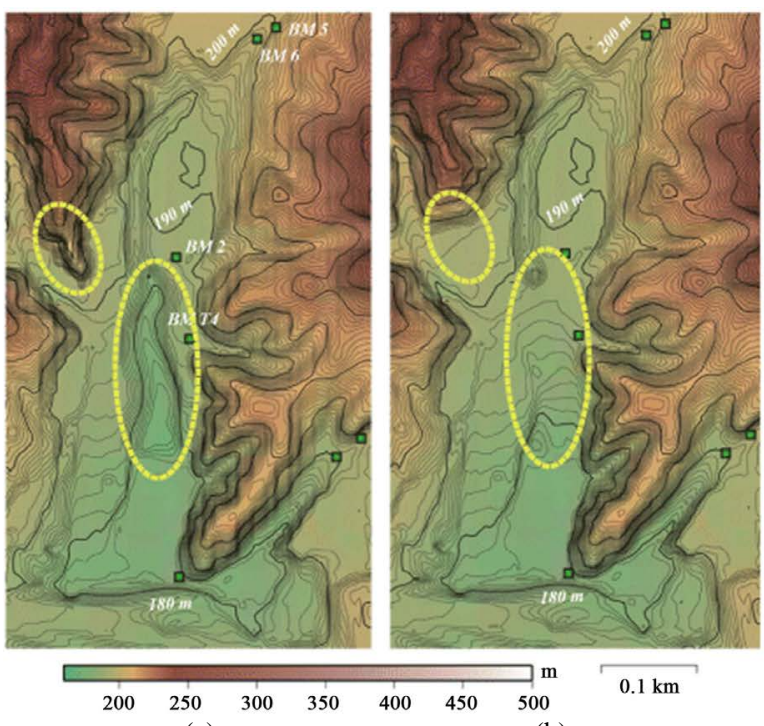

(a)

(b)

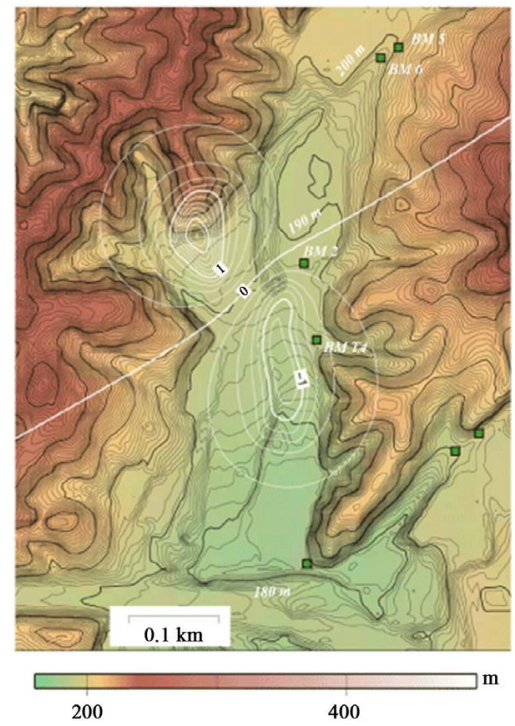

(B)
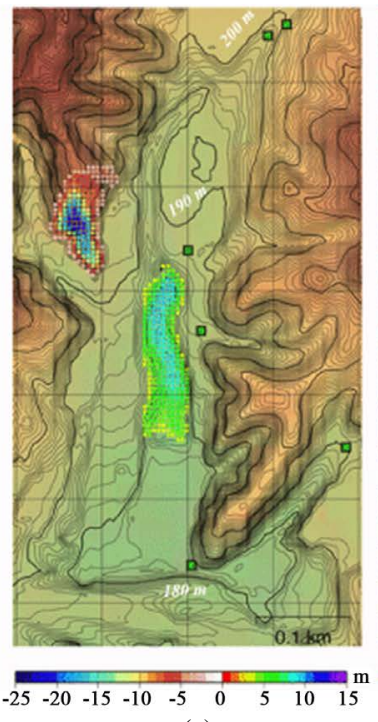

(c)

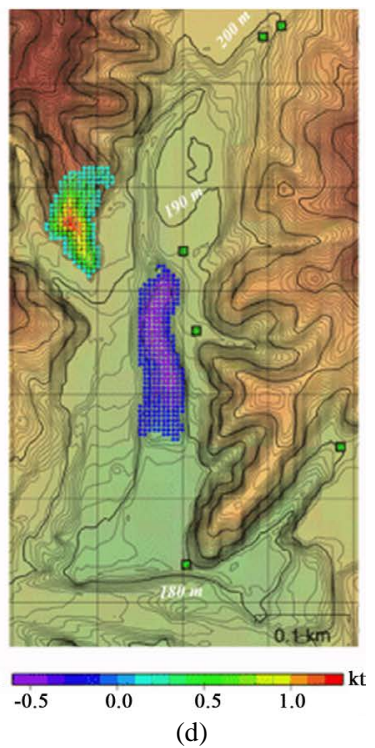

(d)

(A)

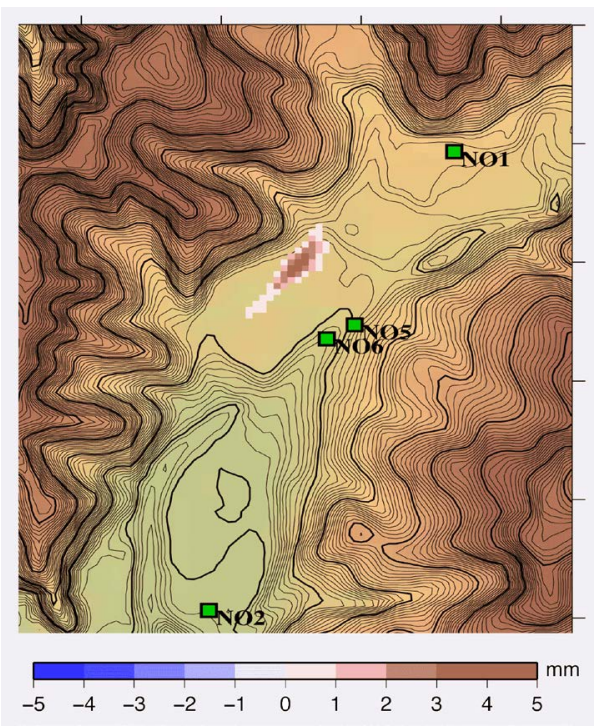

(C)

Figure 3. (A) Configuration change of grand surface, load change, and estimated vertical deformation of load on/off by developments cross to BM 2 ((a) and (b) topographical maps before and after the development constructions, (c) differences of topography, (d) load changes by constructions); (B) Estimated vertical deformation of load on/off by developments in BMs; (C) Estimated vertical deformation of load on/off by excavating shafts in BMs. 
We estimate the volume changes in terrain based on a topographical map of 1:10,000 by Mizunami-shi and a digital $5 \mathrm{~m}$ mesh data by GSI. In calculation, a $10 \mathrm{~m}$ deep valley was buried, and a $25 \mathrm{~m}$ high hill was removed. The both volume changes of buried remove are estimated to be $93 \times 10^{3}$ ton.

Reference [13] discusses the vertical deformation caused by loading off of remove rock complex by quarry development. We estimate the elastic deformation by loading on and off following the method of [13] based on a $5 \mathrm{~m}$ mesh data. We modified his formula to input the values of S-wave velocity, Poisson's ratio, rock density, and we employ the data of [14], which are $1100 \mathrm{~m} / \mathrm{s}, 0.3$, and $2000 \mathrm{~kg} / \mathrm{m}^{3}$.

Maximum deformation is calculated the subsidence of $-0.49 \mathrm{~mm}$ at $\mathrm{BM} 4$, and other deformations are less than $0.1 \mathrm{~mm}$ in any BMs (Figure 3(B)).

We should check the load off by the excavating. The diameter of the main and ventilation shafts is $6.5 \mathrm{~m}$ and $4.5 \mathrm{~m}$ respectively. When excavating depth arrived to $500 \mathrm{~m}$, the total load off is about $56.4 \times 10^{3}$ ton. This load off is given the uplift of $1-2 \mathrm{~mm}$ at BMs 5 and 6 (Figure 3(C)).

As results, we progress the discussion with no concern of vertical deformation effect caused by the load on/off of development project and excavating shafts.

\subsection{Time Series of Vertical Deformation}

As shown in Figure 2, ground subsidence was generally ongoing at BMs nearby evacuating shafts. Moreover, subsidence is dominated through the survey periods of 7.5 years, expecting the uplift of $2 \mathrm{~mm}$ in the period of 1 year after 2011 Tohoku earthquake. The time series of vertical deformations at all BMs are shown in Figure 4. Maximum subsidence is detected $18 \mathrm{~mm}$ at BM 2 near by the evacuating shafts through the 9-year period. However, BMs 5 and 6 are established in 2006, the subsidence of $18 \mathrm{~mm}$ is also detected at BMs 5 and 6 for 6.5 years. It is suggested that the maximum subsidence is occurred cross to the shafts.

There was a progress of subsidence at the 2011 Tohoku Mega Thrust earthquake on March 11, 2011, just after the leveling survey in March 9. Deformation was changed to uplift following the 2011 Tohoku earthquake. About $1 \mathrm{~mm}$ uplifts were detected at few BMs nearby the shafts by the leveling in August 2011. However, in February 2012, about 2 mm uplifts were observed at almost all BMs not only close to shafts.

There are reported groundwater level changes associated with earthquakes (e.g., [15]). Reference [16] also discussed the co-seismic ground water elevation in Togari borehole, which is located 300m south from the evacuating shafts and ground water mainly supplied from the lignite-bearing formation of lower Toki Group at about $200 \mathrm{~m}$ depth [16]. It is characterized groundwater level rise anytime of earthquake occurrence at Togari borehole. Groundwater level rise of $13 \mathrm{~m}$ was observed following the 2011 Tohoku earthquake at the borehole [17]. Same co-seismic groundwater level changes are reviewed in boreholes around MUI [18]. The changes are not only rise but also drawdowns, including with different time responses, it suggests that co-seismic groundwater level changes are more complex.

\section{Groundwater Drawdown and Ground Subsidence by Pumping Water from Shafts}

Precise leveling is conducted, firstly, in February 2004, and it is repeated every year for eight years until March 2011, and two times a year for two years in 2011 and 2012. However, the shaft excavating was begun in July 2003; it was shallow than 20 m deep in February 2004.

\subsection{Groundwater Level Drawdown Amounting to $60 \mathrm{~m}$}

There is a lot of spring in the excavating shafts, and it needs the draining the spring. Generally, discharges from the shafts were increasing with the excavating depths. The discharge volume of drainage was about $700 \mathrm{~m}^{3} / \mathrm{day}$ in 2012. The time series of excavating depths of the shafts and discharge volumes a day reported by MUI are shown in Figure 5. In Figure 5, the groundwater level observed at Togari groundwater level observation borehole of TRIES and ground deformation detected at BM 2 by the precise leveling are shown. Togari borehole is located $300 \mathrm{~m}$ south from the shafts with $230 \mathrm{~m}$ deep. Main groundwater is discharged at the depth of $-130 \mathrm{~m}$ GL [16]. The water level in the borehole is recorded every $0.1 \mathrm{sec}$ as digital data.

The BMs of 5 and 6 are located at the distance of $50 \mathrm{~m}$ from the excavating shafts, and they are closer than BM 2. However, they were established in 2005 and two years later than BM 2. As shown in Figure 4, the time series of vertical deformation on BMs are almost same patterns. Of course, subsidence values are ranging from 


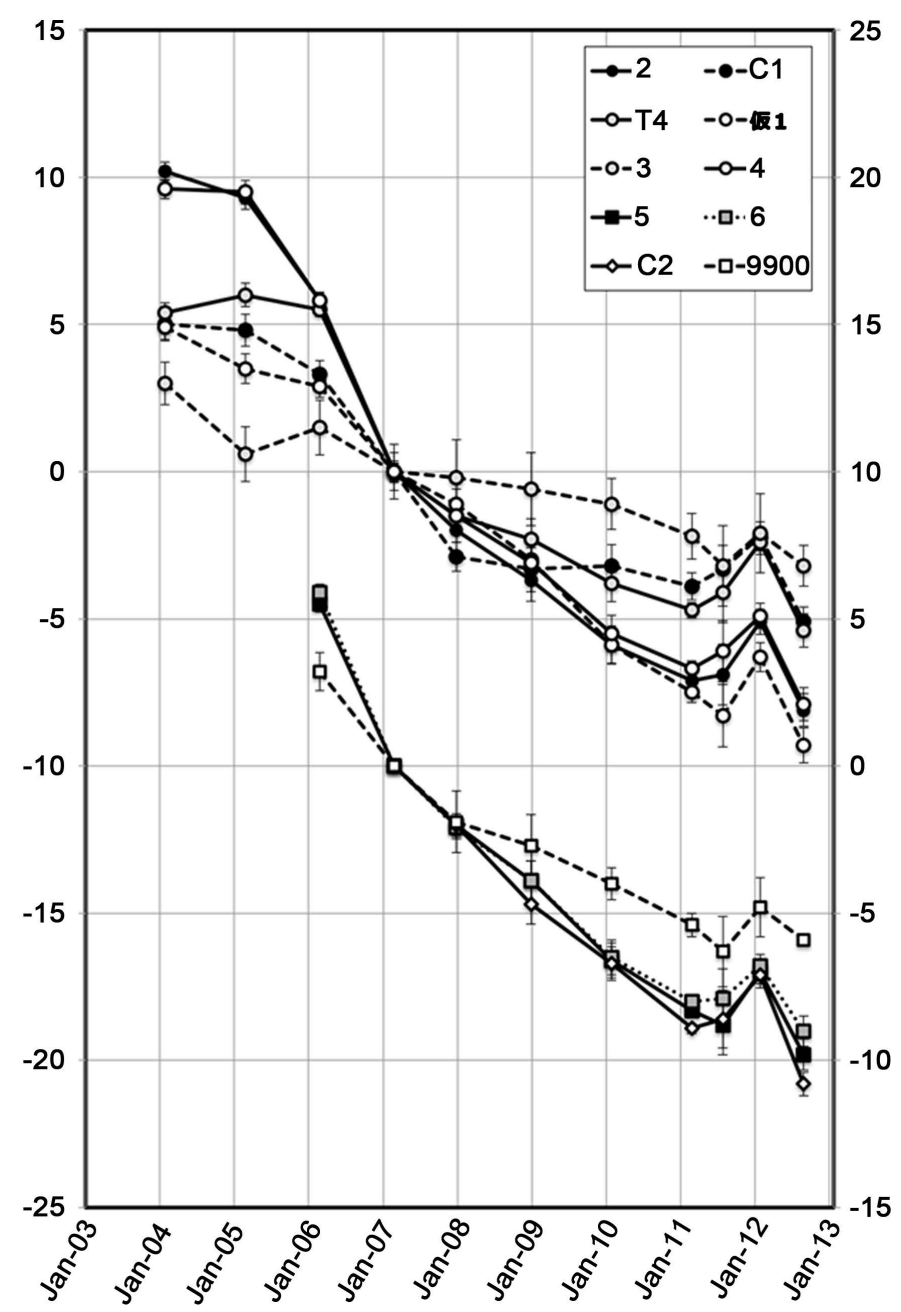

Figure 4. Time series of vertical deformation in BMs established in 2004 and 2006, of the leveling network in the period of 2004-2012.

$10 \mathrm{~mm}$ to $20 \mathrm{~mm}$ for 7 - 9 years. Unfortunately, BM 5 and 6 located close to the shafts were established in 2006. Then we plot the time series at BM 2 in Figure 4. BM 2 is located $300 \mathrm{~m}$ southward from the shafts.

Around the excavating shafts, there are distributed Mizunami Group of Miocene sedimentary rocks in $180 \mathrm{~m}$ depth, and Toki Granite of Cretaceous rocks under $180 \mathrm{~m}$ depth (Figure 5). Coal-bearing formations are laid in the lower Mizunami Group and Toki Granite.

From Figure 5, it firstly reveals positive correlative relationship between discharge volume of groundwater from the shafts and excavating depth, ground water level in Togari borehole and subsidence at BM 2. At the excavating depth of $500 \mathrm{~m}$, the discharge is reached over $700 \mathrm{~m}^{3} /$ day and drawdown of groundwater level is amounting to $60 \mathrm{~m}$, and subsidence is over $18 \mathrm{~mm}$ at BM 2. The discharge of the shafts controlled the groundwater level drawdown and subsidence at BMs close to the shafts.

Of course, time series of discharge suggests some events of discharge. There are some events, such as the first rapid increasing over $400 \mathrm{~m}^{3}$ /day in July 2005 (Event 1), the interrupt pumping in November 2005 (Event 2), the resurgence of pumping after the pump system replace in April 2006 (Event 3), co-seismic increment of discharge in March 11, 2011 (Event 4), and same co-seismic increment in December 2011 (Event 5). These events surely positive influences on the groundwater level in Togari borehole, and sometimes we detect some ground deformation by the yearly or half-yearly precise leveling.

Of course, time series of discharge suggests some events of discharge. There are some events, such as the first rapid increasing over $400 \mathrm{~m}^{3} /$ day in July 2005 (Event 1), the interrupt pumping in November 2005 (Event 2), the resurgence of pumping after the pump system replace in April 2006 (Event 3), co-seismic increment of discharge 


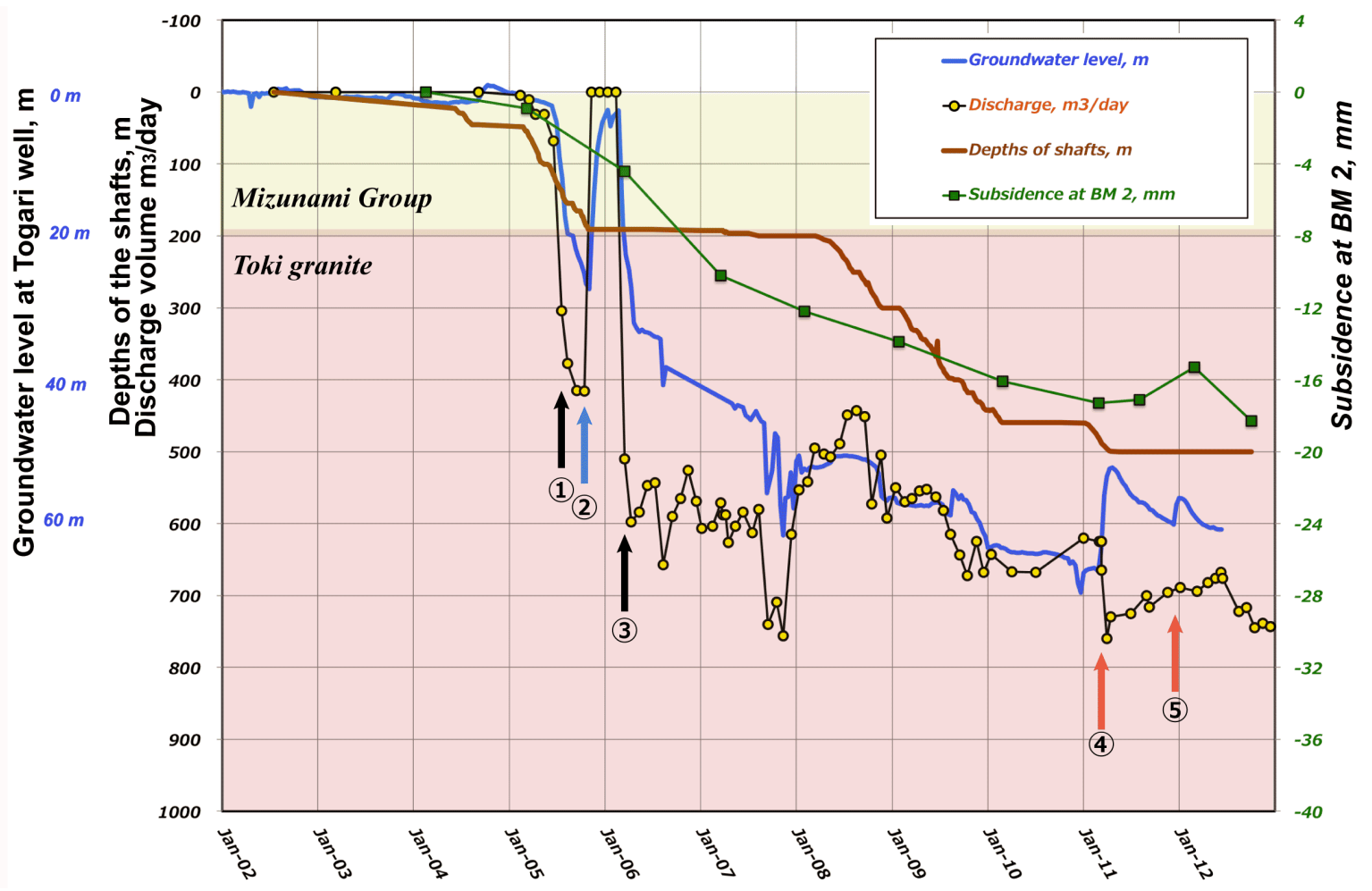

Figure 5. Time series of shaft depth, discharge volume from the shafts observed by MUI, ground water level change in Togari borehole by TRIES, and ground deformation observed in BM 2.

in March 11, 2011 (Event 4), and same co-seismic increment in December 2011 (Event 5). These events surely positive influences on the groundwater level in Togari borehole, and sometimes we detect some ground deformation by the yearly or half-yearly precise leveling.

Event 1: First Rapid Increasing in July 2005

The groundbreaking of the excavation was July 2003, however really excavating was in 2004 in MUI. Until a excavation depth was shallow then $100 \mathrm{~m}$ in June 2005, discharge was also less than $100 \mathrm{~m}^{3} /$ day. In July, excavation depth of main shaft arrived to $115 \mathrm{~m}$, and discharge was over $300 \mathrm{~m}^{3} /$ day. The groundwater level synchronously was drawing down to $-20 \mathrm{~m}$ from -1 - $2 \mathrm{~m}$ GL.

As the precise leveling was done in March 2005, and March 2006, there is no data of ground deformation by leveling.

\section{Event 2: The Interrupting Drain Operation in November 2005}

Until the excavation depth of the shaft reached $150 \mathrm{~m}$ GL in September 2005, the discharge was increasing over $400 \mathrm{~m}^{3} /$ day. It is just the depth of the Toki coal-bearing formation layer. The discharge over $400 \mathrm{~m}^{3} /$ day was overwork of the drain system, so that the system was interrupted in November 2005.

After the interruption of the drain system, the groundwater level was recovering and rose rapidly up to $10 \mathrm{~m}$ in November 2005, and $20 \mathrm{~m}$ in December 2005. In January 2006, two months after the interruption of drain, the groundwater level was recovered and rose up $-2 \mathrm{~m}$, which is corresponded to groundwater level at the $100 \mathrm{~m}$ excavating depth in May 2005.

As there was no leveling in the period, vertical deformation around the shafts was not detected. However, tilt meter of the ASKANIA-type was recording in the observation vault at a distance of $300 \mathrm{~m}$ south from the shafts since November 2005 [19].

When the groundwater level was recovering of about $20 \mathrm{~m}$ in the period of November 2005 to January 2006, meter detected the remarkable uplift tilting amounting to $600 \mathrm{msec}$ in the north-northeast. It suggested that uplift was processed around the shafts.

Event 3: The Resurgence of Drain System in April 2006

After the reinforcement of the drain system, discharge was resumed with displacement of $500-600 \mathrm{~m}^{3} /$ day in 
March 2006. Immediately, the groundwater level began to draw down rapidly, and it reached to $-20 \mathrm{~m}$ GL in about 20 days in late March, and to $-30 \mathrm{~m}$ GL in late April. The excavation was also operated again after the discharge, and it arrived $190 \mathrm{~m}$ GL in late June.

As the leveling has done on March 19-23, 2006, the groundwater level already drew down to $-20 \mathrm{~m}$ GL. As results, a subsidence of $-4 \mathrm{~mm}$ at BM 2 referred to the height in March 2004 was detected. On the other hand, A subsidence tilting in the north-northeast of $600 \mathrm{msec}$ was observed by the ASKANIA-type tilt meter until early April 2006, which is just a mirror image of uplift tilting at the period of groundwater level drawdown [19].

The excavating was almost interrupted around $-200 \mathrm{~m} \mathrm{GL}$, and discharge was small changing around 600 $\mathrm{m}^{3} /$ day until March 2008. Contrastingly, the groundwater level was drawing down, and it reached $-50 \mathrm{~m}$ GL in 2008. The precise leveling was done almost every March in the period of 2006 - 2008. Subsidence of $8 \mathrm{~mm}$ was detected at the BM 2 for 2 years of 2006-2008.

In April 2008, the excavation was re-operated and the shafts were arriving a depth about $-460 \mathrm{~m}$ GL in February 2010. Subsidence was also progressed and up to $4 \mathrm{~mm}$ at BM 2 for two years in 2008-2009.

\section{Event 4: Coseismic Increment of Discharge in March 11, 2011}

At the 2011 M9.0 East Japan mega thrust earthquake on March 11, 2011, the groundwater level rose $13 \mathrm{~m}$ from $-66 \mathrm{~m}$ GL to $-52 \mathrm{~m}$ GL at the Togari observation borehole described above [17]. Coseismic increasing spring waters in the drifts and shafts are already pointed out and discussed based on the crustal deformation observation in 1960s [20].

Coseismic groundwater level raises less than $1 \mathrm{~m}$ are frequently detected in Togari observation borehole [16]. It is also observed at the 2004 Sumatra M 9.1 earthquake. As spring volumes in shafts are observed as pumping up volumes every hour, it is measured the increasing spring with volume of $100 \mathrm{~m}^{3} /$ day distinctly. The discharges of the shafts were also increasing about $100 \mathrm{~m}^{3} /$ day and it is increasing over $700 \mathrm{~m}^{3} /$ day.

Some co-seismic groundwater level changes in Togari borehole were discussed [15], and all level changes show the rise. Around MUI, they occupy the many boreholes within $10 \mathrm{~km}$ distance and monitoring the groundwater level changes. Reference [18] already discussed the ground water level changes at the 2011 Tohoku earthquake.

The coseismic groundwater level changes are not simple. However, some boreholes show rises, same as Togari borehole, some show the draw down. Moreover, the patterns of rise and drawdown are also more complex. Some boreholes show a dilatory rise after co-seismic water level drawdown [18].

Another boreholes close to the shafts monitored by MUI recorded the groundwater level rise [18]. In stank contrast, there were some boreholes shows the groundwater drawdown in some distances of $1-10 \mathrm{~km}$ from the shafts (Niwa et al., 2012). These coseismic groundwater drawdowns and rise suggest the complex system of the ground water.

1) The largest coseismic water level changes are detected at Togari and MUI observation boreholes as the water level rises.

2) A water level rise at Togari borehole is amounting to $13 \mathrm{~m}$ in a day after the earthquake, and the level rise continued to for one month.

3) Vertical displacements of 1 - 2 mm uplift are recognized at the benchmarks only close to the shafts in August 2011, and displacements of two mm uplift are remarked at all benchmarks. It is clearly the different response between water level rises and ground uplifts.

4) An increasing spring in shafts is observed as increasing discharges pumped up from the shafts. Until the coseismic changes of the 2011 earthquake, the water level drawdowns are following the growing discharges, however, water level rises are detected this time.

Event 5: Coseismic Increment by M5.1 near Field Earthquake in December 24, 2011

Coseismic groundwater level rise of $5 \mathrm{~m}$ was observed by the felt earthquakes occurred beneath Mizunami in December 2012. The earthquake is M5.1 and the epicenter of the earthquake is located at $54 \mathrm{~km}$ deep, which is just located in the sub-ducting slab of the Philippine Sea plate. The earthquake mechanism suggests a normal fault type striking in N-S. It is caused under the east west extension in the subduction plate [21]. However, this is no significant observation on the change of the discharges in the shafts.

\subsection{Groundwater Level Drawdowns and Ground Subsidence around the Shafts Following the Increase of Discharge}

The Figure 5 shows the time series of vertical displacements at the BM 2 in a distance of $200 \mathrm{~m}$ from the shafts 
in the period of seven years in 2004 to 2011. In the figure, we plot the time series of discharge volume from shafts observed by JAEA and depth of the main shaft every month, and ground water level observed by TRIES.

It is clearly that following the excavating depth, increasing of discharge from the shafts, and the groundwater level drawdown in Togari borehole, BM 2 is subsidence with time. After the 2011 East Japan earthquake, the precise leveling was done in August 2011, February 2012, and September 2012, and small uplifts are detected in August 2011 and February 2012. In September 2012, the subsidence is recovered, and it reaches about $2 \mathrm{~cm}$.

In the plan of MUI, the excavated shaft would be infilled after the examination by MUI. If there are no pumping the discharge of the shafts, the groundwater level would basically recover same as no pumping experiments in November 2004. However, many ground subsidence caused by pumping the groundwater never recover in alluvial plains. In many cases, the ground subsidences are as the result of consolidation behavior of sedimentary layer.

In some case, groundwater is pumping up in shallow alluvium for seasonal agricultural water in summer or snow-melt-water for road in heavy snowfall area along the Japan Sea coast in winter. In their area, ground subsidence is detected in the period of pumping in summer or winter. However, the ground subsidence is also recovered in the period of no pumping in winter or summer [22]. The ground subsidence and recover are caused by poro-elastic body.

Authors observed some recovery of grand subsidence by the tilt meter at the time of no pumping discharge for few months and pumping water in the borehole for few hours around the excavating shafts in MUI (Matthias et al., 2013; Asai, 2014, personal communication). There is one possibility of pore erratic body of granite as the mechanism of the ground subsidence. It is necessary to discuss the mechanism of ground subsidence, including the supply source and transport system of groundwater around the shafts. In order to make clear ground water flow, the precise leveling network was extended to $32 \mathrm{~km}$ distance to around area in 2012 and more surveys of ground magnetism and gravity in 2014.

\section{Conclusions}

Japan Atomic Energy Agency (JAEA) has developed the excavating $500 \mathrm{~m}$ deep shafts in the Toki granite in Mizunami, central Japan, since 2004. As a part of monitoring of ground water circulation, crustal deformation, and seismic activities following the excavating shafts, the precise leveling has been done to discuss the ground deformation around the shafts since 2004. As a result of the precise leveling, $20 \mathrm{~mm}$ subsidence is detected at benchmarks nearby the shafts until 2012.

As following depths of the excavation, ground water discharges are increasing to $700 \mathrm{~m}^{3} /$ day and grand water level is declined up to $70 \mathrm{~m}$ in the borehole close to the shafts. Simultaneously, ground subsidence is observed in the benchmarks nearby the shafts, corresponding to the ground water level declination. The water level was recovered instantly at the time of the tentative draining discontinue in November 2005, and declined after the resuming discharges. Following the 2011 Tohoku mega thrust earthquake and M5.6 earthquake occurred beneath Mizunami, the ground water level was ascending $13 \mathrm{~m}$ and $6 \mathrm{~m}$ respectively. The uplifts of $2 \mathrm{~mm}$ are detected at the benchmarks nearby the shafts with some time lag. After then, the ground water level and ground deformation were turned to declination and subsidence, respectively.

Because the groundwater of $700 \mathrm{~m}^{3} /$ day is still discharged from the shafts, until now, mass ground water steadily requires an ongoing supply from not only local area but also the surrounding area of the shafts. We expanded the leveling network peripherally to the area of $5 \times 10 \mathrm{~km}$ in 2012, and leveling routes were laying over $30 \mathrm{~km}$. Since then, precise leveling was repeated in every year until 2014. In the near future, we will discuss the regional groundwater flow based on vertical deformation by our precise leveling.

\section{Acknowledgements}

We appreciate Dr. H. Aoki, a former director of TRIES to establish the research project in 2004, and Dr. M. Okubo, a chief researcher of TRIES, to joint our discussion and give many suggestions. We also express our appreciation to the researchers of Tono Geoscience Center, JAEA to discuss the data of excavation, and anonymous referees to contribute convenient suggestions on our manuscript.

\section{References}

[1] Holzer, T.L. and Galloway, D.L. (2005) Impacts of Land Subsidence Caused by Withdrawal of Underground Fluids in 
the United States. Reviews in Engineering Geology, 16, 87-99. http://dx.doi.org/10.1130/2005.4016(08)

[2] Abidin, H., Andreas, H., Gumilar, I., Sidiq, T.P. and Fukuda, Y. (2012) Land Subsidence in Coastal City of Semarang (Indonesia): Characteristics, Impacts and Causes. Geomatics, Natural Hazards and Risk, 4, 1-15.

[3] Iida, K. (1986) Analysis of Land Subsidence in the Nobi Plain. Bulletin of Aichi Institute of Technology; Part B, 165-173. (In Japanese)

[4] Sato, H.P., Abe, K. and Ootaki, O. (2003) GPS-Measured Land Subsidence in Ojiya City, Niigata Prefectures, Japan, Engineering Geology, 67, 379-390. http://dx.doi.org/10.1016/S0013-7952(02)00221-1

[5] Baldi, P., Casula, G., Cenni, N., Loddo, F. and Pesci, A. (2009) GPS-Based Monitoring of Land Subsidence in the Po Plain (Northern Italy). Earth and Planetary Science Letters, 288, 204-212. http://dx.doi.org/10.1016/j.epsl.2009.09.023

[6] Biessy, G., Moreau, F., Dauteuil, O. and Bour, O. (2011) Surface Deformation of an Intraplate Area from GPS Time Series. Journal of Geodynamics, 52, 24-33. http://dx.doi.org/10.1016/j.jog.2010.11.005

[7] Yamada, N., Wakita, K., Hiroshima, T. and Komazawa, T. (1990) Geology of the Iida District. With Geological Sheet Map at 1:200,000. Geology Survey of Japan, 111. (In Japanese with English Abstract)

[8] Saegusa, H. and Matsuoka, T., Eds. (2011) Final Report on the Surface-based Investigation (Phase 1) at the Mizunami Underground Laboratory Project. JAEA-Research, 2007-043. (In Japanese with English Abstract) http://jolissrch-inter.tokai-sc.jaea.go.jp/pdfdata/JAEA-Research-2010-067.pdf

[9] Tono Geoscience Center, Japan Nuclear Cycle Development Institute (2001) Mizunami Underground Research Laboratory Project Results from 1996-1999. http://www.jaea.go.jp/04/tono/miu_e/publ/tn74002003004/h8-11-all.pdf

[10] Japan Nuclear Cycle Development Institute (2002) Research Project on Geoscientific Research of Mizunami Underground Research Laboratory. JNC TN7410 2001-01, 1-30. (In Japanese with English Abstract)

[11] Shimo, M., Kumamoto, S., Onoe, H. and Saegusa, H. (2011) Mizunami Underground Research Laboratory Project (Study on Hydrogeology in Crystalline Fractured Rock) Hydrogeological Modeling and Groundwater Flow Simulation Based on Data of Hydraulic Impacts during Construction of MIU Facilities (FY2006-2007). JAEA-Research, 2011-017, 1-132. (In Japanese with English Abstract)

[12] Itoigawa, J. (1980) Geology of the Mizunami District, Central Japan. Monograph of the Mizunami Fossil Museum, 1, 1-50. (In Japanese with English Abstract)

[13] Tada, T. (1982) Elastic Deformation of Earth’s Crust Caused by Man-Made Surface Unloading. Journal of the Seismological Society of Japan, 35, 427-433. (In Japanese with English Abstract)

[14] Sato, M., Aoki, T. and Nakama, S. (2004) Data Collection on Basic Mechanical Property of Mizunami Group. JNC TN7450 2003-002.

[15] Itaba, S., Koizumi, N., Toyoshima, T., Kaneko, M., Sekiya, K. and Ozawa, K. (2008) Groundwater Changes Associated with the 2004 Niigata-Chuetsu and 2007 Chuetsu-oki Earthquakes. Earth Planets Space, 60, 1161-1168.

[16] Asai, Y. (2006) Study on the Mechanism of Co-Seismic Groundwater Level Changes. Ph.D. Dissertation, Graduate School of Science, Hokkaido University, Sapporo.

[17] Asai, Y., Ishii, H. and Tanaka, T. (2011) Co-Seismic Ground-Water Level Changes Associated with the 2011 of the Pacific Coast of Tohoku Earthquake. Proceedings of the Japan Geoscience Union Meeting, Chiba, 7-11 February 2011.

[18] Niwa, M., Takeuchi, R., Onoe, H., Tsuyuguchi, K., Asamori, K., Umeda, K. and Sugihara, K. (2012) Groundwater Pressure Changes in Central Japan Induced by the 2011 off the Pacific Coast of Tohoku Earthquake. Geochemistry, Geophysics, Geosystems, 13, Article ID: Q05020. http://dx.doi.org/10.1029/2012GC004052

[19] Queitsch, M., Jentzsch, G., Weise, A., Ishii, H. and Asai, Y. (2014) Pumping Induced Pore Pressure Changes in Tilt Measurements Near a Fault Zone in Mizunami, Japan. Proceedings of the International Association of Geodesy Symposia, 139, 113-118. http://dx.doi.org/10.1007/978-3-642-37222-3_14

[20] Shichi, R. and Iida, K. (1973) Observation of Crustal Deformation at Inuyama (III). Journal of the Geodetic Society of Japan, 19, 8-21. (In Japanese with English Abstract)

[21] Saiga, A. and Okubo, M. (2013) Source Mechanism of an Intraslab Earthquake in the Philippine Sea Plate: The M 5.6 Earthquake under Eastern Mino, Gifu Prefecture, Japan. Zishin, 66, 1-10. (In Japanese with English Abstract)

[22] Tobita, M., Munekane, H., Kaidzu, M., Matsusaka, S., Kuroishi, Y., Masaki, Y. and Kato, M. (2004) Seasonal Variation of Groundwater Level around Tsukuba. Journal of the Geodetic Society of Japan, 50, 27-37. (In Japanese with English Abstract) 